\title{
The Embodiment of Zhuangzi's Ecological Wisdom in Chinese Literati Painting (wenrenbua 文人畫) and Its Aesthetics
}

\author{
Loreta POŠKAITE்*
}

\begin{abstract}
**
The paper deals with the relation of Daoist (mainly Zhuangzi's) ecological ideas on inter-penetration and "communication-without-communication" of things to Chinese landscape and bamboo painting, more specifically, to the ideas about the harmonization of the painter with the things (scene) painted in the process of producing the artwork. Its purpose is to explore a more nuanced, philosophical and non-Eurocentric interpretation of this peculiar kind of harmony of things or their "unity in particularity", as inspired by Zhuangzi's ideas and seemingly embodied in Chinese literati painting. For this purpose, the paper introduces few conceptual models, formulated by Western sinologists, as the particular philosophical schemes for the understanding of Zhuangzi's epistemology and cosmology, and then discusses their applicability with regard to the relationships between the painter and the world, as presented in early and classical Chinese painting aesthetics and theory.
\end{abstract}

Keywords: Harmony, Dao, thing ( $w u$ 物), ecology, transformation

Utelešenje Zhuangzijeve ekološke modrosti v kitajskem slikarstvu literatov (wenrenhua 文人畫) in njegova estetika

\section{Izvleček}

Prispevek se ukvarja $z$ daoističnimi (večinoma Zhuangzijevimi) ekološkimi idejami o interpenetraciji stvari in »komunikaciji-brez-komunikacije« ter $z$ njihovo povezavo s kitajskim krajinskim slikarstvom, še posebej z idejami harmonizacije slikarja s stvarmi (podobami), ki jih naslika v procesu stvarjenja umetniškega izdelka. Namen prispevka je to proučiti in prikazati nekoliko bolj niansirano, filozofsko in ne-evropocentrično interpretacijo tovrstne specifične harmonije stvari ali njihovo »enost v posebnosti«, navdihnjeno $\mathrm{Z}$ Zhuangzijevimi idejami in utelešeno v kitajskem slikarstvu literatov.

\footnotetext{
* Loreta POŠKAITÉ, Associate Professor at Centre of Oriental Studies, Vilnius University. lposkaite[at]yahoo.com

** I am very grateful for two anonymous peer review readers for their comments and suggestions.
}

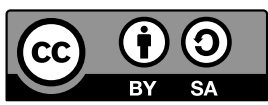


S tem namenom prispevek najprej predstavi nekaj konceptualnih modelov, ki so jih formulirali zahodni sinologi kot posebne filozofske sheme za razumevanje Zhuangzijeve epistemologije in kozmologije, ter poskuša prikazati njihovo uporabnost $\mathrm{z}$ upoštevanjem odnosov med slikarjem in svetom, kot je prikazano $\mathrm{v}$ zgodnji klasični estetiki in teoriji kitajskega slikarstva.

Ključne besede: harmonija, dao, stvar (wu 物), ekologija, transformacija

\section{Introduction}

Chinese literati painting (wenrenhua 文人畫) in both landscape and bamboo genres, as well as its related theory, have fascinated Western artists and sinologists since the beginning of 20th century, thus forming their general understanding of Chinese classical aesthetics. This fascination has fostered a search for the main differences between the principles and aims of Chinese and Western painting, as well as their basis in a particular ontology and cosmology. ${ }^{1}$ Many scholars agree that the greatest impact on Chinese landscape painting and its ideas was made by classical Daoist philosophy, especially by Zhuangzi (as a book), which, according to Li Zehou, is aesthetic in its essence. As he points out, Zhuangzi

urged people to take an aesthetic, contemplative attitude towards life as a whole: discount gain and loss, success and failure, right and wrong, merit and demerit; forget the self and things, subject and object, the self and others, and thereby let the self and the whole universe blend into one ( $\mathrm{Li}$ 1995, 155).

In the same vein, but with different emphasis, Scott Cook remarks, that

Zhuangzi's philosophy offers us the chance to learn how to live our lives aesthetically, to appreciate that all we encounter are simply themes and variations upon the ever-changing melody of the Great Transformation. He teaches us how to hear and appreciate the Great Harmony (...). The panpipes of Heaven may be enjoyed by all, for they exclude nothing and embrace all things as equal members of a diverse and intricate orchestra. (Cook 2003, 76)

1 The beginnings of such comparative analysis could be found in the famous books by Laurence Binyon (Binyon 1923), George Rowley (Rowley 1947), Benjamin Rowland (Rowland 1954), and this approach is still popular in the literature on Chinese art. 
This particular contemplative, aesthetic attitude and the holistic vision of the world are the most important features, which relate Zhuangzi with the literati painting in general, and landscape and bamboo painting in particular. Many Chinese painters and poets have admired and tried to embody in their art his ideal of spiritual freedom, spontaneity, wandering and reclusiveness, as the best ways to enjoy this all-embracing harmony of change or "transformative harmony". ${ }^{2}$ They also tried to follow Zhuangzi's methods for attaining this spontaneity, such as forgetting one's self (wang wo 忘我), losing myself (wu sang wo 吾喪我), riding of self (wuji 無已), “non-action” (wuwei 無爲), “fasting of the mind” (xin zhai 心齋), grasping things with one's mind (xin 心) or vital energy ( $q i$ 氣), “taking off one's robes and stretching out one's legs" (jieyi panbo luo 解 衣般礴贏). ${ }^{3}$ By this, they aimed to follow (or were compared to) Zhuangzi's model persons or examples of self-cultivation and "eco-creativity", such as the cook or butcher Ding, the painter, the catcher of cicadas, the swimmer or carpenter. Some painters were even longing for Zhuangzi's presence in their life and art, considering him the only person who could understand their ideal of spiritual concentration and immersion in things and the universe through their painting.

Such a Daoist ideal of following "the natural way of production", i.e. the Dao (Moeller 2004, 114), ${ }^{4}$ was summed up very well in the famous comment by Fu Zai 符载, Tang dynasty poet and official, when talking about the painting of his contemporary Zhang Zao 張璪:

When we contemplate Master Chang's art, it is not painting, it is the very Tao [Dao] itself. Whenever he was engaged in painting, one already knew that he had left mere skill far behind. His ideas reach into the dark mysteries of things, and for him, things lay not in the physical sense, but

2 For more on the embodiment of the ideal of reclusion in Chinese painting see: Gao Jianping (Gao 1995). Some of the most extensive studies about the application of Daoist ideas and concepts to Chinese painting and aesthetics were written by Russian sinologists, such as Jelena $\mathrm{Za}$ vadskaya, Leonid Bezhin, and Krivtsov. See their books in Russian: Bezhin 1982; Krivtsov 1993; Zavadskaya 1975.

3 It is important, that, according to Gao Jianping, the latter compound, which was used in Zhuangzi for the description of the painter's freedom from ritual norms and conventional behavior, later turned to refer in Chinese art criticism to the act of painting in general, and the spontaneous, natural artistic expression in particular. More on this see: Gao 1996, 81-82.

4 I totally agree with Hans-Georg Muller, that a Daoist understanding of the art is more concerned with the concept of artisanship and the process of creation of the piece of art rather than with the concept of beauty and the piece of art itself (and in the case of landscape painting-with the nature itself rather than with the depiction of nature or its imitation). See his: ibid., 114-5. 
in the spiritual part of his mind. And thus he was able to grasp them in his heart, and make his hand accord with it." ${ }^{5}$

The main emphasis in this fragment, according to Gao Jianping, is on the process (act) of painting itself and understanding of the highest mastery in painting, influenced very much by Zhuangzi's ideas and concepts, as mentioned above (Gao 1996, 78-80). But this fragment also informs us of the highest aim of the painter, which is - like that of a Daoist sage or fully realized person - to deploy the Dao, or to blend completely with one's environment. This sense of the inseparability of the painter and the world (things) depicted in the painting has often been described by Western and Chinese interpreters as "the unity of (or harmony, intimacy between) the human and nature", or even as "the act of reverence for nature", and contrasted with the Western model of "the separateness of human and nature" in the comparative analysis of Chinese and Western painting and their aesthetics, as well as their ecological ideas. ${ }^{6}$ Such descriptions and juxtapositions were certainly influenced by the Neo-Confucian idea of tian ren he yi 天人合一("harmony as oneness of Heaven and human"), which, as Wang Zhenfu demonstrates, was before and after Zhang Zai formulated and discussed by various poetic and non-poetic phrases, such as yuanshi bundun 原始混沌 (primordial chaos), wuwo tongyi 物我同一 (“things and me are the same"), zhu ge bun qi 主客浑契 ("the host and guest are in muddy agreement"), tian ren ganying 天人感应 ("the resonance between heaven and human"), tian ren yi qi 天人一气 ("heaven and human united by one vital energy"), tian ren xiang tong 天人相通 (“interpenetration of heaven and human"), tian ren wu jian 天人无间 ("non-separateness of heaven and human"), tian ren xiang yu 天人相与 ("the mutual participation of heaven and human"), and so on. (Wang 2006, 9)

What seems to me problematic in such stereotypical formulas and discussions of a Daoist model is an implicit Eurocentric tendency to view (even by naming) "nature" and "the human" as two separate realms, although there is no clear division between them in Daoist classical philosophy nor in Chinese landscape painting and its aesthetics. Such a formula simplifies and fails to explain the peculiarity of the Daoist (Zhuangzian) holistic or "ecological" worldview, as well as the harmonious relationships between the painter and the world—if we wish to understand them from Zhuangzi's perspective of all-pervading oneness. One of the reasons

5 (觀夫張公之藝非畫也, 真道也。當其有事, 已知遗法穖巧, 意冥玄化, 而物在靈府, 不 在耳目。故得於心, 应於手, 孤姿绝狀, 觸毫而出, 氣交冲漠, 與神爲徒). Except from "Preface on Observing Secretary Chang Painting Pines and Rocks", quoted from: Bush et al. (1985, 85).I have preserved the translators use of Giles-Wide English transcription of Chinese names and terms.

6 See for example: Rowley 1947, especially the chapter on Man and Nature; Graham 2004, 35-36. 
for such simplification lies, as it seems to me, in the abstract nature of the term "harmony", which is too often used as a synonymous with the terms "ecological" or "ecology" - since there is not one but many sorts of harmony. Maybe the most detailed and specified understanding of Daoist ecology, or ecological relationships, is offered by various authors of the comprehensive collection of articles Daoism and Ecology. They emphasize the notion of "transparent communication (tong)", the tendency for all things "to flourish naturally", the need to construe our action toward the environment "as an action toward the self", the notion of harmony as the "natural flourishing (ziran) of the ten thousand things", the need to subvert and transcend the dichotomy of nature/culture, to avoid an anthropocentric perspective, and to maintain "the cosmological interdependence of heaven, earth and humankind" as a persistent leitmotifs in Daoist thought and religion. ${ }^{7}$ However, I would prefer to describe those ecological relationships between people and the environment (or things) using Zhuangzi's phrase "to join with others without joining with others" and "to do with others without doing with others" (相与于无 相与, 相爲于无相爲), which was used for the characterization of the friendship among three men-Zisang $\mathrm{Hu}$, Meng Zifan and Ziqin Zhang (Zhuangzi, ch. 6 in Watson 1968, 86). ${ }^{8}$

No less problematic to me seems the tendency to describe the unity between the painter and things depicted in his painting by Western terms of subject/object relations-for example, as their mutual conversion or "identification of subject and object". Moreover, these terms are often used in the Western translations of Chinese texts on painting and the related studies. ${ }^{9}$ This is despite the fact that they seem misleading and not useful in the context of Chinese painting (especially literati) aesthetics for at least two reasons. First, because of the absence of the "substance ontology", based on the idea of primordial separability and the stability of material forms and identities in Daoist (Zhuangzian) philosophy. Second, because of a far broader, processual and perspectival understanding of the word “thing" ( $w u$ 物) in Daoism—-the word, sometimes translated in the texts on

7 A summary of those notions is presented in Miller et al. (2001,150-3).

8 Wang Rongpei translates this as "befriend others without showing any friendship and help others without leaving any trace”. See: Zhuangzi 1999, 103.

9 For example, in his translation of Zhang Yanyuan's Li dai ming hua ji 歷代名畫記 W.R. Acker translates the Chinese word wu 物 (thing) as "object": "Object and self alike forgotten" (wu wo liang wang 物我两忘). See: Acker 1954, 192. The same was done by Gao Jianping (Gao 1996, 157-8). Another example: "the appearances of his objects [seemed to] issue entirely from nature" is from the English translation of Zhu Jingxuan's text in: Bush et al. $(1985,84)$. Elsewhere Susan Bush also writes about Su Shi's description of artistic creation "as the fusion of self and object" (Bush 1971,41). 
Chinese painting as "object", which seems to me also misleading. ${ }^{10}$ As such, later in this article I would like to discuss whether it would be possible to interpret the relationships between the painter and the world (things) with the help of special conceptual schemes, which were formulated by the researchers of Daoist (Zhuangzi's) philosophy for the more nuanced and appropriate understanding of a Zhuangzian "ecological" vision of the world and experience of its oneness. I would not like to ignore Chinese scholars, who made considerable contributions to contemporary interpretations of Daoist aesthetics in general, ${ }^{11}$ and Zhuangzi's aesthetics in particular (especially Xu Fuguan), but for my purpose I will concentrate on the interpretations by Western sinologists, since they are more related to the problems of Eurocentric views of this subject.

\section{Zhuangzi’s Ecological Vision of "Intraworldly Mysticism"}

This is one of the schemes, as suggested by Lee Yearley, to describe Zhuangzi's radical vision. Such a vision, according to Yearley, implies a "hold and let go" approach. It consists of focusing "intently on the perception that is directly present before you but pass on to another perception when a new perception comes or the old one fades" (Yearley 2010, 127-8). It neither aims at the experience of union with some immutable and transcendent reality, in which two spheres or realities - the immutable one and that of a changing, particular individual—still remain separate, nor at the experience of unity, in which the individual immerses

$10 W u$ 物could mean, depending on the context, not only material and separate objects or bodies, but also human beings and other creatures, senses, situations, which are understood as various manifestations of vital energy ( $q i$ 氣) and thus united or inter-related exactly by this $q i$ 氣. For example, Taehyun Kim discerns three features of wu 物 as being in Zhuangzi: their materiality (they are "material objects of sense, language, and cognition; they have external forms and names"), changeability (they are "restricted in time and space, and are dependent on mutual counterparts or opposites") and origin in Dao. (See Taehyun 2009, 6-7) Moreover, in Laozi even Dao is refered to as a “thing" in the phrase 道之物 (Laozi, chapter 21) —in this case wu物 means rather "something", or "that", or "this"-what is indeterminate or out-of-description. R. Ames and David L. Hall even go so far as to translate this word as "process" ("as for the process of way-making"), commenting that Dao, as participatory, fluid and processual way-making, "contains within it the eventful phenomena we identify as those "things" and" images" that make our lives, including of course ourselves. According to the authors, due to privileging process over substance, continuity over discreteness, "we must understand "things ( $w u$ 物)" as both processes (happenings) and events". Accordingly, wanwu 万物 ("the myriad things") should be understood as refering "to the unsummed totality of all particular processes and events as they constitute this world", "everything that is happening", while Zhuangzi's expression wuhua 物化—as suggesting "the mutuality and interpenetration of all forms of process, as one 'thing' transforms to become another" (Ames and Hall 2003, 107, 67).

11 See for example: Liu Chengji's article on the relation of Daoist aesthetics to contemporary eco-aesthetics: (Liu 2006, 236-249) 
into oneness as the "sole reality of universe". According to Yearley, intraworldly mysticism does not seek absolute reality, but instead aims "to see the world in a new way", "to obtain a new viewpoint on normal experience", or simply to see "life as a cinema show, a series of passing frames, a kaleidoscope of ever-changing patterns" (ibid., 128). In other words, it urges us to look at beautiful objects and then forget them, as if viewing all life like "an aesthetic panorama": "Life is a series of aesthetically pleasing new beginnings, and all such beginnings should be grasped and then surrendered as change proceeds" (ibid., 134). ${ }^{12}$ This is the ability to grasp each new moment as it comes and surrender as it goes. It combines attachment and detachment to any thing, event, scene, even oneself-like in a mirror, and admits only one reality, the reality of change.

How is this form of "intraworldly mysticism" related to landscape or bamboo painting and its aesthetics? First, the view to life as a series of aesthetically pleasing moments or scenes was most evidently embodied in Chinese landscape paintings through their format. This enables us to view those paintings as changing panoramas of scenes and images, as marked by their moving perspectives or multiperspectivism, without a clear beginning, centre and end. Second, it helps to explain philosophically the peculiarity of the artist's "wandering consciousness". Harold Roth, in developing Yearley's model and following Zhuangzi's discourse, calls it the "yinshi 因是mode of consciousness", "the adaptive "that's it" position or "Dao-centered" mode of being, and contrasts it to weishi 爲是一the contrived "that's it" mode of consciousness or "ego-centered" mode of being. The latter he characterizes as one's inclination to look at the world according to one's pre-established position and viewpoint, using a rigid and fixed worldview with a rigid attachment to oneself and one's predispositions, while the former - as the ability to abandon a fixed viewpoint, a single perspective, and rather to respond to things or situations spontaneously, according to the situations and things themselves, which are self-affirming (zishi 自 是) and “naturally so" (tianran 天然) (Roth 2010, 202-7). ${ }^{13}$ This yinshi or "knowing how", "because of this" mode of consciousness could be achieved only through the going along with myriad things (wan wu 万物), as it was demonstrated in Zhuang$z i$ by the paradigmatic examples of various masters and their outstanding skills.

The use of this wandering or yinshi consciousness in painting can be illustrated by a conversation between Wen Tong (Yuke) and a visitor, to whom Wen Tong talks about his painting as follows:

12 Yearley states that the mystical experience of union with unchanging reality is a form of "mysticism of union" that was developed in the West, while the experience of monistic unity-as a form of mysticism with a monistic base, is more peculiar to Indian subcontinent.

13 See also Cook $(2010,84)$, especially note No. 40, in which he presents a summary of Guo Xiang and other sinologists comments on yinshi consciousness in Zhuangzi. 
Why, what I love is Tao: I have gone beyond bamboo. When I lived in retirement on the south slope of Mount Ch'ung, I made my home in a grove of tall bamboo, and looked and listened in quietness without its affecting my mind. In the morning the bamboo were my friends, in the evening, my companions; I drank and ate amongst them and stopped and rested in their shade (...). At first I looked and enjoyed it, then I enjoyed it and was not conscious of doing so. Suddenly forgetting the brush in my hand and the paper in front of me, I rose up instantly and made bamboo in quantities. How is the impersonality of the Creator any different from this? (Bush 1971, 38-39) $)^{14}$

These words suggest that the painter has to be able not only to make bamboo a part of his life and his life a part of bamboo, but after this experience and the pleasure it brings to forget the bamboo, and even the enjoyment of it (and Zhuangzi would perhaps add, then to forget the forgetting itself). He thus has to forget the very agent of enjoyment, that is himself. In other words, he has to be able to enjoy without enjoyment (as the parts "looked and listened in quietness without affecting my mind", and "enjoyed it and was not conscious of doing so" would suggest). Thus, one of the most important conditions for such "wandering consciousness", or combining attachment and detachment, communication and co-existence with the world without mental involvement or deliberation, is exactly such forgetfulness.

One of the earliest examples of the importance of the notion of forgetfulness in Chinese painting practice and theory can be found in the famous early work of art criticism, A Record of the Famous Painters of all the Dynasties (歷代名畫記), by Zhang Yanyuan 張彥遠. He describes the act of painting by Gu Kaizhi as follows:

Object and self forgotten, he (Ku K'ai-chih) departs from forms and leaves knowledge behind. When the body can truly be made to be like dry wood, and the mind can truly be made to be like dead ashes, is this not to have attained mysterious principles? It is what can be called the true way (Tao) of painting. (Acker 1954,192) $)^{15}$

To forget in this case means to look at things not from one's personal perspective, but rather from that of emptiness and/or oneness; not to see oneself in things, but rather things as they are by themselves and how they change. Instead of reflecting

14 The original Chinese text is given at the end of this book, p. 190, fragment No.62

15 物我两忘。離形去智。身固可使如槁木。心固可使如死灰。不亦臻於妙理哉。所謂畫之 道也. 
on himself as an agent of any activity, the painter just follows the changes of things (wu bua 物化) without knowing how these happen. Only such a view allows him to establish a particular "ecological" relationship with the world, namely, to communicate with things in the most direct and "energetic" way, by combining involvement with non-involvement, and then to depict things in the most natural way without imitation or intentions. In other words, the painter acts like Dao, which acts without acting, that is, without imposing its will or view on others. Following Zhuangzi's logic of paradox or the coexistence of opposites, I would rather call such a relationship "communication without communication" (or "non-communicative communication") and "unity in separateness".

\section{The Applicability of the Concepts of Vitality ( $q i$ 气) and Idea ( $y i$ 意)}

Such a particular "ecological" relationship is also revealed in Chinese painting and its theory by the concept of $q i$ 氣 (vitality, energy, breath), which became one of the most important Chinese aesthetic categories, especially in theories of literature and painting. Due to its importance, painting was conceived as the exchange of vital energy among the world (things), painter and viewer. Such a view could be justified by the first and the most important canons or elements ( $f a$ 法) of painting, as formulated by Xie He's 謝赫—“vital resonance and life movement” (qiyun shengdong 气韻生動). I will not engage into a discussion of the meaning of $q i$ and the first principle, or the problems of the latter's translation into Western languages and the changes in its meaning over the history of Chinese art criticism, since they were and still are quite extensively discussed by many scholars in China and the West (Acker 1954, xxix-xxxiii; Lin 1967, 35-37; Sze 1956, 33-54). ${ }^{16}$ I would just like to pay an attention to the ambiguity of the "agent" of this qiyun shengdong. Who (whose?) or what's qiyun should be manifested or embodied in the painting?

This seems to be one of the most important questions, since its answer directs the interpretation of the relationship between the painter and the world. The opinions of scholars here differ considerably. Some consider qiyun the manifestation of Dao in its perpetual motion (the rhythmical movement of yin and yang) (Sze 1956, 54), or the hidden sense behind the artistic images and forms which gives a feeling of aesthetic satisfaction, or the mood, tone and atmosphere (Krivtsov 1993, 71; Lin 1967, 108). ${ }^{17}$ Others relate it to the individuality, heart-mind (xin 心)

16 One of the best analyses of $q i$ in association with other aesthetic terms in Chinese painting theory and various meaning of the first principle was done by Gao 1996, especially pp. 89-94, 103-111

17 However, Lin Yutang remarks that such an understanding of qiyun as a mode or atmosphere has prevailed only since the Yuan dynasty. 
and actions of the painter, understanding $q i$ as his "psychological force" and vigour, and yun - as the cyclical action of the painter's brushstrokes, revealing his spiritual characteristics (Gao 1996, 91, 107-8). Still others describe it "as sympathetic vibrations of the "spirit" between the painter and the critic", or as "some sort of transference of emotion from person to person", or as the turning of the painter into the thing to be painted (Acker 1954, xxxii). Regardless of the details of this point, qiyun comes from a subtle vibration or resonation between separate "subjects", thus reminding us of the abilities of some masters in Zhuangzi to listen to things with their $q i$ or shen 神 rather than ears, and to respond without involvement. Even if qiyun is the manifestation of the vigour of the painter, then it was accumulated and developed through close interaction with things or other forms and kinds of vital energy - especially when we keep in mind that most landscape painters of the literati school tended to represent their inner vision, born after long contemplation of natural scenery, instead of representing the real scenery or particular place. ${ }^{18}$

Moreover, I would like to extend the question asked above-whose shengdong is manifested in the painting? The answer could be-that of nature or things as they are by themselves. The best model for learning to convey this movement of life for Chinese painters is (and was) bamboo. The painter has to convey not its form, but rather the moving impulse for its growth. He has to comprehend and represent in the painting the whole process of bamboo's growing from its roots to the tips of its leaves, as it stated by Su Shi:

When bamboo first comes into being, it is only an inch-long shoot, but the joints and leaves are all in it. It develops from cicada chrysalises and snake scales to swords drawn out eighty feet, because this development was immanent in it. Now when painters do it joint by joint and add to it leaf by leaf, will this be bamboo? Thus, in painting bamboo one must first have the perfected bamboo in mind. (...) Does this only apply to bamboo? When Tzu-yu (Su Ch'e) composed the "Ink Bamboo Fu" for Yu-ko, he wrote: The cook merely cut up oxen, but a nourisher of life

18 James Cahill notes the words of Dong Qichang 董其昌 on the difference between the real landscape and landscape painting: "From the standpoint of splendid scenery, painting cannot equal (real) landscape. But from the standpoint of the sheer marvels of brush and ink, (real) landscape is not at all the equal of painting'. In other words, if it is beautiful scenery you want, go to nature, if it is painting, come to me." (Cahill 1982, 4-5). But Cahill also remarks, that we (Westerners) do not have to think about Chinese landscape painting as only the representation of ideal scenery, as we are accustomed to do. He shows in his book that many landscape paintings had their origins in the pictures of particular places-mountains, rivers, and so on. The practice of painting types of ideal landscape, conceived as replicas of the universe, developed only in the Song dynasty. But even in those times this type or genre of landscape painting was only one among several (ibid., 5-13) 
learned from him; wheelwright Pien carved wheels, but the reader of books agreed with him. Now, when you make use of these bamboos and I take you to be a man of Tao, is this wrong? (Bush 1971, 37) ${ }^{19}$

Like Zhuangzi's paradigmatic masters, the painter has to transform himself into bamboo or, more exactly, into its life movement. To achieve this he has to forget or to lose his "self" (that is, his own perspective or point of view). But he also has to forget the bamboo, in order to be able to look into (and not at!) the world from the perspective of unity. This perspective is suggested in Su Shi's words "one must first have the perfected bamboo in mind". They indicate the concept of "idea" ( $y i$ 意) and the associated strategy of “ $y i$ preceding the brush" (yi zai bi xian 意在笔先), which became one of the most important in literati painting theory. Although the meaning of $y i$ is no less ambiguous than that of $q i{ }^{20}{ }^{20}$ it seems to me that this concept is very helpful for the understanding the particular aesthetic and ecological relationship of "attachment-in-detachment" between the painter and the world (or things to be painted).

As Gao Jianping remarks (and this remark seems to me very important), an idea (yi) was formed in the painter's mind as the result of knowing or realizing "why it is so" (or why a thing is as it is) (Gao 1996, 153). Such a realization comes only after long contemplation of nature-bamboo, trees, mountains at different moments of life, weather, and time, ${ }^{21}$ or after immersion into their existence. But then, after reading Su Shi's texts, Gao Jianping raises the question: "What was the painter really looking at when he took up the brush and contemplated intently? Was he looking at bamboo, or at silk or paper?" His answer is, that he was looking at the silk (paper), because at the moment of painting "there was actually no bamboo present in front of him. It was by virtue of his spiritual concentration that he saw in his mind the image of bamboo", and this image seemed to him more true than the image of the real bamboo seen before, because it "involved the realization of a more profound communication with the object" (ibid., 153-5).

My answer to these questions would be that we are talking about a few different moments or transformations, which take place in the process of painting

19 For the Chinese text see ibid.,190, fragment No.60

20 Gao Jianping summarizes its general meaning as "the general strategy for realizing the intention and for moving brush" (Gao 1996, 153). But it could also suggest some meaning behind the visible forms and images (which reminds us of Zhuangzi's longing to talk with somebody who has forgotten words), as well as something which unites the world, painter and viewer-in this case its meaning could be related to Dao, shen 神 or qiyun shengdong 氣韵生動.

21 For example, Guo Xi writes extensively about how different mountains and trees look at the different time of the day, weather, etc. 
(including the preparatory process of contemplating the things to be painted). It would thus be too risky and simplistic to interpret the relationship between the painter and the world as that between "subject" (the painter's "self") and "object" (the thing to be painted). It is very difficult to discern the appearance and disappearance of the boundaries between the painter and the world in this process, since they are simultaneously united and not-united. It would be better to think that there is a painter, and there is also bamboo, mountains and rivers, and they simply meet in the process of painting when the moment of new transformation comes. The painter forgets himself or his previous experience and simply reacts to the movement of nature like an echo, just grasping and manifesting "vital resonance and life movement” (qiyun shengdong 气韻生動). Moreover, as indicated by Zhang Yanyuan, and cited above, this movement brings the painter (and the viewer of the painting) to the mysterious principles (妙理) or common source of all beings.

Such a coexistence rather reminds me of the metaphor of the panpipes of heaven (tianlai 天策) or the great harmony (da he 大和), described vividly in Zhuangzi chapter 2: "Blowing on the ten thousand things in a different way, so that each can be itself-all take what they want for themselves, but who does the sounding??. ${ }^{22}$ Similarly, the painter has to represent the individuality of each thing/scene by implying their common roots, or their primordial state of non-differentiation. In other words, he acts like that Daoist sage who, according to Zhuangzi, "is called walking two roads" at once (wei liang xing 謂两行), or looking at things and himself from the non-movable and empty "pivot of Dao" (dao shu 道樞), from which all opposites ("this" and "that") seem to coexist, be equal and support each other.

\section{Zhuangzi's Worldview as "Omnicentric Holism"}

One of the best philosophical explanations of Zhuangzi's view, as discussed above, was presented by Brook Ziporyn in his conceptual model of "omnicentric holism" (bian zhong zheng ti lun 遍中整体论). ${ }^{23}$ According to this, the one who does the sounding is nothing other than "the self, always both present and absent in the sounds", and such simultaneous presence and absence of the self can only be spoken of by considering the question "Is there really a true self or not?" (Ziporyn 2003, 42). One can avoid a clear answer to this if one takes the position of the "value paradox", on which this model of omnicentric holism is based. Ziporyn describes this as the ability to hold two contradictory perspectives (be they

22 吹万不同, 而使其自己也, 咸其自取, 怒者其谁邪? (Watson 1968, 37)

23 I have consulted with the author himself for the translation of this term into Chinese. 
philosophical positions, epistemological or moral values, identities, emotional moods) at the same time, instead of adhering to any one of them ("this" or "that"), since "each perspective constitutes its own whole, is intrinsically correct, and includes its opposite" (ibid., 35). The position of the "value paradox" also allows one "to switch perspectives" or respond without storing, since all different perspectives at the same time, in their interconnection, form one perspective or the perspective of oneness.

Such a switch of perspectives was spoken of by Guo Xi: "There are also different ways of looking at landscapes: if one looks at them with the heart of the woods and the streams, their value becomes great, but if one looks at them with proud and haughty eyes, their value becomes quite low." (Siren 1956, 221)24 As we see, these ways of looking (perspectives) are different, but Guo Xi privileges the contemplation of the landscape from an insider's perspective, or more exactly, from the intersection of perspectives ("the heart of the woods and the streams"). Such contemplation removes any of the distance and detachment which is implied by the English word "landscape" but is absent in Chinese terms, such as shanshui 山 水, shilin 石林 or yi qiu yi he一丘一壑 (“one hill and one valley”).

However, one of the most important insights that the model of "omnicentric holism" has, and one that underpins its applicability in understanding the relationship between the painter and the world ("things") in Chinese painting theory, is not so much in the emphasis of Zhuangzi's claim that the "true man has no fixed identity" while at the same time privileging the perspective of oneness, but rather in the idea that "a thing entails a perspective", or even "a thing is a perspective". This means that all things or "objects" ( $w u$ 物) are open to each other. Every thing includes the emotional perspective of its perceiver ("subject"), and accordingly "each perspective has not only a "this" but also a "that" (Ziporyn 2003, 35, 46) 25 $^{25}$ like a mirror or an echo. Such a process of mirroring and overlapping of things (perspectives) is evident in the whole process of the painting as well as its reception. At the start, the painter has to look into nature and simultaneously open the inner source of his heart-mind, in order to preserve its images or forms and to transform them into an inner vision, which will then be simply reflected (i.e., will come out directly) through his brush. Most literati painters and theoreticians were convinced that the brush just follows the impulses of the heart-mind, as the container of all things and images (which reminds us of Zhuangzi's idea of listening with one's heart-mind), but it also could be added that the painter sees himself in

24 看山水亦有體。以林泉之心臨之則價高。以驕侈之目臨之則價低

25 Here the author quotes Zhuangzi's: "Without them there is no me, without me there is nothing to pick them out." (ibid., 42) 
the scene while the scene reflects the painter. All things support and animate each other-mountains become water's face, while the waters make mountains come alive; the pavilions and kiosks become water's eyes and eyebrows, while the paths give movement to the mountains, and the forests give them life. None of these things seems to lose its individuality (particularity), but rather this individuality is preserved only through the interactions that occur with the individuality of others, and thus the borders between things vanish.

As such I will conclude here that the question of the presence/absence or losing/ gaining of one's "self" (in this case, the painter's self) seems very important for Western minds, or those who understand one's identity as definite and substantial. But it seems less important for Zhuangzi and Chinese painters, who were more concerned with the question of how to open or empty one's heart-mind (xin) in order to comprehend the world in its wholeness. They preferred to talk about emptiness and lose as the only ways to gain one's fullness or the experience of oneness. This is because Chinese painters, like Zhuangzi, prefer to look into the world and the myriad of things from the perspective of oneness or great harmony.

Finally, I would like to point to another concept, which helps us to better understand this experience. It can be illustrated by Su Shi's famous poem on Wen Tong's painting:

When Yü-k'o painted bamboo,

He saw bamboo, not himself.

Nor was he simply unconscious of himself:

Trance-like, he left his body.

His body was transformed into bamboo,

Creating inexhaustible freshness.

Chuang Chou is no longer in this world,

So who can understand such concentration? (Bush 1971, 41) ${ }^{26}$

Bush comments on this poem by making an allusion to the story from Zhuang$z i$ about the bell-stand carver-how "the nature of the carver joins with that of the wood" (ibid., 41). However, for me the most important word in this poem is transformed. Transformation (bua 化, bianbua 变化, wubua 物化) is one of the key terms in Zhuangzi's cosmogony, ontology and ecology. It helps in particular to explain the transitivity of "self" and "other", or "this" and "that", as well as the coexistence and interpenetration of things (and the human beings among them).

26 For the Chinese text see ibid., 190-1, fragment No.66 
The idea of the all-pervasiveness of such change was even more emphasised by Zhuangzis commentator Guo Xiang, who notes:

Of the force which is without force there is none greater than change and transformation; thus it opens heaven and earth so as to press on to what is new, bears up mountains and hills so as to dismiss what is old; thus is does not stop for a moment, (...), the myriad things of heaven and earth are never at any moment not shifting. The world is completely new yet we take it as old. (...). A mountain alters daily and we look at it as if it were in the past...Therefore, the self I was is not the self I will be or now am (...). (Zhang 2002, 202)

I would suggest that painting, and especially landscape painting is maybe the most meaningful and impressive visual embodiment of this process of transformation, or generation and regeneration, especially if we have in mind a common idea about the origins of painting from Yijing and trigrams as symbols and images of cosmic change, which have prevailed in Chinese painting theory since its beginning. Such an understanding of painting culminated in Shi Tao's 石涛theory of "one stroke" (yi bua 一畫) and "method-of-no-method" (or "the method created out of no-method"一wu fa sheng you fa 無法生有法). The idea of one stroke in this master landscape painter's theory has many meanings. It is both a symbol of cosmic unity and at the same time that ultimate One which transforms itself from the highest simplicity $(p u)$ and becomes a kind of potentiality or source of all the multiplication of the world. It is the same one stroke from which the 64 hexagrams of Yijing are formed. It also reminds us of the smallest (separate) things, which already contain Dao as oneness, or the first touch of the brush, from which come all other lines and images as the manifestations of the vibrations of vitality (qiyun 氣韵).

Consequently, the "method-of-no-method" is understood as grasping (shou 受) the cosmos in its oneness by the painter's heart-mind, or as the method of nature (or Dao) itself. For example, in the chapter on "Transformation" (bianbua) from his famous essay Hua yu lu 畫語錄, Shi Tao writes:

Painting is the greatest method for representing the world in the process of transformation and interaction, for capturing the essential beauty of landscape's dynamic forms, the eternal activity of creation, the succession of day and night and of the seasons. (Strassberg 1989, 64) 27 $^{27}$

27 夫畫天下變通之大法也。山川形勢之精英也。古今造物之陶治也。陰陽氣度之流行也。 
According to Shi Tao, such a representation is possible because of the moulding of those transformations by the painter himself. But the context of his whole theory still suggests that the highest aim of artistic creativity for him, as well as for some other of the Northern Song literati, is the painter's immersion in the natural process of transformation and being imbued with the naturality or so-of-itself (ziran). The painted landscape thus becomes as real as the reality around the painter, who paints as if he travels with his body and mind through the mountains and rivers, and the viewer joins his travels. This is why landscape painting and its contemplation is sometimes equated with various forms of Daoist meditation, such as "Guarding the One" (shou yi) and visualization (cunxiang). The images (xiang), born in the painter's heart-mind as the result of his communication with nature (paraphrasing Shi Tao, "the mountains are in me, and I am in the mountains") and self-transformation, are transformed into the really existing images.

Finally, if the absence or presence of one's self was not the main concern of Chinese painters and aestheticians, then what was the highest aim of forgetfulness in the process and reception of painting, especially landscape painting? As many texts on this issue suggest, it was the experience of an atmosphere of wonder, of something inexpressible and unexplainable, which indicates this inexhaustible oneness and is referred to by various terms, such spirit (shen 神), qiyun 氣韵, Dao as invisible centre, and so on. I would in fact suggest that it is this wonder which is a necessary and particular element of the Daoist perception of the beauty (miao 妙), and which makes it different from the Confucian or mainstream Western understanding of beauty. This particular form of Daoist beauty is manifested in Chinese painting and its aesthetics in close relation to other Daoist concepts, such as the mysterious (xuan 玄) and emptiness ( $x u$ 虚), or as well as in the mutual production of emptiness and fullness ( $x$ u shi xiang sheng 虚实相生). These terms all refer to the activity of Dao as something all-pervasive and harmonizing, which keeps all the kaleidoscopic patterns and changes of the world together.

It is exactly this infinity of space, time and atmosphere, or more exactly-this emptiness or whiteness (bai xu 白虚), which unites all perspectives, all things depicted in a painting, as well as the painter and the viewer. It invites one to view landscape or bamboo painting not as simple representation of the outer reality or inner imagination of the painter, but as a kind of sacral art, which unites those two realms and perspectives sing only black and white- blackness in whiteness and whiteness in blackness. Even more, it is the meeting point of being (you 有) and non-being ( $w u$ 無), or that what is formed and unformed. As such, the presence or presentiment of this uniting and mysterious emptiness makes the painter and viewer be receptive not to the visible forms of things, but rather to the stage 
of their emergence from the "invisible-undifferentiated fount", or "the process of taking form and coming into actuality" (Jullien 2009, 23).

\section{Conclusion}

In my discussion and application of particular conceptual schemes, as formulated by other sinologists, I wanted to demonstrate that the Zhuangzian ideas of wandering, of "the pivot of Dao" and "traveling two roads at once", are very helpful for a better understanding of the particular ecological relationships between the painter and the world in Chinese painting, which, accordingly, could be characterized rather as "communication in non-communication", or "attachment and detachment". Such an interpretation could be supported by the particular understanding of thing $(w u)$ as perspective rather than "object", and transformation (bua) as the most important characteristic of reality.

This is why the creative act in Chinese painting, especially landscape painting, cannot be treated as the act of paying homage to nature, as was sometimes interpreted in the West in order to stress the differences between Western and Chinese models of the relationship between people and nature. Landscape painting is not an act of homage to nature, since nature here (in the painter's and viewers' minds) does not exist as an external object of adoration, emotive attachment or aesthetic pleasure. This is because Chinese painters preferred to view nature not from the human perspective, but rather from a macrocosmic (or Dao axis) perspective of the unity of things, which also include the human point of view. But it is this unity which helps both the painter and the viewer to not be attached to any particular thing or perspective, thus fostering the attitude of "engagement with detachment".

However, such view, fundamentally influenced by Zhuangzi's ideas about the simultaneity of oppositions and simultaneous arising of things, should be considered as only one among many in the tradition of Chinese literati painting and aesthetics, and also as having not only aesthetic but also therapeutic effects. This is why contemplation of landscape painting was considered by some Chinese, and later-by many Westerners, as a way to improve one's health, and to maintain a balanced relationship with natural environment. As Zong Bing 宗炳, the author of the first essay on landscape painting Preface on Landscape Painting (Hua shanshui $x u$ 畫山水敘), wrote, "Sages, possessing the Tao, respond to things. The virtuous, purifying their thoughts, savour images. As for landscape, it has physical existence, yet tends toward the spiritual." (Bush 1985, 36) ${ }^{28}$

28 聖人含道應物。賢者澄懷味像。至於山水。質有而趨靈 


\section{References}

Acker, William Reynolds B., transl. 1954. Some T'ang and pre-T'ang texts on Chinese Painting. Leiden: E.J. Brill.

Ames, Roger T., and David L. Hall. transl. 2003. Daodejing. "Making This Life Significant". New York: Ballantine Books.

Bezhin, Leonid. 1982. Бежин Л.Е. Под знаком “ветра и потока" Bezhin L.E. Pod znakom "vetra i potoka". (Under the Sign of the "Wind and Streams" (fengliu 风流)). Moskva: Nauka.

Binyon, Laurence. 1923. Painting in the Far East: An Introduction to the History of Pictorial Art in Asia, Especially China and Japan. London: E. Arnold.

Bush, Susan. 1971. The Chinese Literati on Painting. Su Shib (1037-1101) to Tung Ch'i-ch'ang (1555-1636). Cambridge: Harvard University Press.

Bush, Susan, Shih, Hsio-yen, eds. and comps. 1985. Early Chinese Texts on Painting. Cambridge, Massachusetts, London: Harvard University Press.

Cahill, James. 1982. The Compelling Image. Nature and Style in Seventeenth-century Chinese Painting. Harvard: Belknap Press of Harvard University Press.

Cook, Scott, ed. 2003. "Harmony and Cacophony in the Pipes of Heaven." In Hiding the World in the World, 64-87. New York: State University of New York Press.

Gao, Jianping. 1995. "The Reclusive Spirit in Chinese Painting." The Stockholm Journal of East Asian Studies 6: 102-24.

—. 1996. "The Expressive Act in Chinese Art. From Calligraphy to Painting." Acta Universitatis Upsaliensis 7. Uppsala: Uppsala University.

Graham, Archie. 2004. "Landscape of Silence." Journal of Chinese Philosophy 31 (1) (March): 33-45.

Jullien, Francois. 2009. The great Image Has no Form, on the Nonobject through Painting. Chicago: The University of Chicago Press.

Krivtsov, B.А. Кривцов. 1993. Эстетика даосизма Estetika daosizma (Daoist Aesthetics). Moskva: Fabula.

Li, Zehou. 1995. "Zhuangzi and Chan Buddhism."In Contemporary Chinese Aesthetics, edited by Zhu Liyun and Gene Blocker, 143-78. New York et al.: Peter Lang.

Lin, Yutang, transl. 1967. The Chinese Theory of Art. London: Heineman.

Liu, Chengji 刘成纪. 2006. "Daojia sixiang yu dangdai shengtai meixue 道家思 想与当代生态美学 (Daoist Thought and Contemporary Eco-Aesthetics).” In Meixue yu wenhua, dongfang yu xifang 美学与文化东方与西方 (Aesthetics and Culture, East and West), edited by Gao Jianping and Wang Keping, 236-49. Anhui jiaoyu chubana she.

Miller, James, et al. 2001. "Sectional Discussion: What Ecological Themes Are Found in Daoist Texts?" In Daoism and Ecology, edited by N. J. Girardot, 
James Miller, and Xiaogan Liu, 341-7. Cambridge, Massachusetts: Harvard University Press.

Moeller, Hans-Georg. 2004. Daoism Explained. From the Dream of the Butterfly to the Fishnet Allegory. Chicago and La Salle, Illinois: Open Court.

Roth, Harold D. 2010. "Bimodal Mystical experience in the 'Qiwulun' Chapter of the Zhuangzi." In Experimental Essays on Zhuangzi, edited by Victor H. Mair. Dunedin: Three Pines Press.

Rowland, Benjamin. 1954. Art in East and West: An Introduction through Comparisons. Harvard: Harvard University Press.

Rowley, George. 1947. Principles of Chinese Painting. Princeton, N.Y.: Princeton University Press.

Siren, Osvald. 1956. Chinese Painting: Leading Masters and Principles. Vol. I. New York: The Ronald Press Company.

Strassberg, Richard E. transl. and comp. 1989. Enlightening Remarks on Painting by Shib-T'ao. Pacific Asia Museum Monographs, No.1. Pacific Asia Museum.

Sze, Mai-mai. 1956. The Tao of Painting. A Study of the Ritual Disposition of Chinese Painting. Bollingen Series XLIX, New York: Pantheon Books.

Taehyun, Kim. 2009. "Reading Zhuangzi Eco-Philosophically." Journal of Daoist Studies 2: 1-31.

Wang, Zhenfu 王振复. 2006. Zhongguo meixue fanchou shi 中国美学范畴史 ( $A$ History of Chinese Aesthetic Categories). Taiyuan: Shanxi jiaoyu chuban she.

Watson, Burton, transl. 1968. The Complete Works of Chuang Tzu. New York: Columbia University Press.

Yearley, Lee. 2010. "The Perfected Person in the Radical Zhuangzi." In Experimental Essays on Zhuangzi, edited by Victor H. Mair, 122-35. Dunedin: Three Pines Press.

Zavadskaya, Jelena. 1975. Esteticheskiye problemy zivopisi starogo Kitaya Завадская Е.В. Эстетические проблемы живописи старого Китая (Aesthetic Problems of the Painting in Early China). Moskva: Iskusstvo.

Zhang, Dainian 2002. Key Concepts in Chinese Philosophy. Beijing: Foreign Languages Press; New Haven and London: Yale University Press.

Zhuangzi. 1999. Translated into English by Wang Rongpei. Library of Chinese Classics, Chinese-English. Hunan People's Publishing House, Foreign Languages Press.

Ziporyn, Brook. 2003. "How Many Are the Ten Thousand Things and I? Relativism, Mysticism, and the Privileging of Oneness in the 'Inner Chapters'. In Hiding the World in the World, edited by Scott Cook, 33-63. Albany: State University of New York Press. 